\title{
To Vaccinate or Not: Impact of Bovine Viral Diarrhoea in French Cow-Calf Herds
}

\author{
Sandie Arnoux ${ }^{1}$ D, Fabrice Bidan ${ }^{2}$, Alix Damman ${ }^{1,+}$, Etienne Petit ${ }^{3}$, Sébastien Assié ${ }^{1}$ and Pauline Ezanno ${ }^{1, *}$ (D) \\ 1 INRAE, Oniris, BIOEPAR, 44300 Nantes, France; sandie.arnoux@inrae.fr (S.A.); \\ alix.damman@gmail.com (A.D.); sebastien.assie@oniris-nantes.fr (S.A.) \\ 2 Institut de L'élevage, 42 rue Georges Morel, F-49070 Beaucouzé, France; fabrice.bidan@idele.fr \\ 3 GDS BFC, 21110 Breteniere, France; etienne.petit.gdsbfc@reseaugds.com \\ * Correspondence: pauline.ezanno@inrae.fr \\ † Present address: Bureau Fédéral du Plan, Rue Belliard 14-18, 1040 Brussels, Belgium.
}

Citation: Arnoux, S.; Bidan, F.; Damman, A.; Petit, E.; Assié, S.; Ezanno, P. To Vaccinate or Not: Impact of Bovine Viral Diarrhoea in French Cow-Calf Herds. Vaccines 2021, 9, 1137. https://doi.org/ 10.3390 /vaccines 9101137

Academic Editor: Kerstin Wernike

Received: 27 August 2021

Accepted: 21 September 2021

Published: 6 October 2021

Publisher's Note: MDPI stays neutral with regard to jurisdictional claims in published maps and institutional affiliations.

Copyright: (c) 2021 by the authors. Licensee MDPI, Basel, Switzerland. This article is an open access article distributed under the terms and conditions of the Creative Commons Attribution (CC BY) license (https:// creativecommons.org/licenses/by/ $4.0 /)$.

\begin{abstract}
Bovine viral diarrhoea (BVD) remains an issue despite control programs implemented worldwide. Virus introduction can occur through contacts with neighbouring herds. Vaccination can locally protect exposed herds. However, virus spread depends on herd characteristics, which may impair vaccination efficiency. Using a within-herd epidemiological model, we compared three French cow-calf farming systems named by their main breed: Charolaise, Limousine, and Blonde d'Aquitaine. We assessed vaccination strategies of breeding females assuming two possible protections: against infection or against vertical transmission. Four commercial vaccines were considered: Bovilis ${ }^{\circledR}$, Bovela $^{\circledR}$, Rispoval ${ }^{\circledR}$, and Mucosiffa ${ }^{\circledR}$. We tested various virus introduction frequency in a naïve herd. We calculated BVD economic impact and vaccination reward. In Charolaise, BVD economic impact was $113 €$ per cow over 5 years after virus introduction. Irrespective of the vaccine and for a high enough risk of introduction, the yearly expected reward was $0.80 €$ per invested euro per cow. Vaccination should not be stopped before herd exposure has been decreased. In contrast, the reward was almost nil in Blonde d'Aquitaine and Limousine. This highlights the importance of accounting for herd specificities to assess BVD impact and vaccination efficiency. To guide farmers' vaccination decisions against BVD, we transformed this model into a French decision support tool.
\end{abstract}

Keywords: epidemiology; model; endemic disease; control strategy; vaccination; economic impact; cattle; BVD

\section{Introduction}

Bovine viral diarrhoea (BVD) is a worldwide endemic disease of cattle [1], leading to abortions, delayed calving and mortality [2]. Despite the fact control programs have been implemented in many countries [3], BVD is still an issue for farmers [4]. After the virus is introduced in a susceptible herd, an epidemic can occur, which often spontaneously fades out because most infected animals are quickly immunized for life [5]. However, the infection of females in mid-gestation could give rise to the birth of persistently infected (PI) calves [6]. PI animals massively shed the virus for life. They have a shortened lifespan, half dying in their first year [7]. They represent a risk for other animals as well as for herds in contact. On the one hand, the high turnover of animals in cattle herds compromises the establishment of a long-lasting herd immunity. On the other hand, contacts with neighbouring herds on pasture and the purchases of animals potentially carrying the virus lead to regular virus reintroductions $[8,9]$. When animals spend a long time outdoor on pasture, such as in French cow-calf herds, there is a particular risk of virus introduction through proximity contacts between neighbouring herds at a period when many females are gestating [10].

Several vaccines are available to prevent BVD virus from spreading into non-infected but exposed herds [11]. Vaccination alone is known not to be sufficient to reach eradication 
at a national scale [11]. In combination with testing, it can lead to eradication but it is generally not economically attractive [12]. However, in the absence of a collective control program, a vaccination performed on a regular basis could help decreasing shedding and new infections in herds exposed to virus introduction. Nevertheless, at this local farm scale, the economic impact of vaccination is not very well known, particularly because BVD spread highly depends on herd characteristics [13], which may impair vaccination efficiency. Such a knowledge would be useful to help farmers decide to vaccinate or not their herd, accounting for herd specificities, such as its size, usage of pasture, calving seasons, etc. In addition, the risk of stopping vaccinating after a few years has not been evaluated yet.

Modelling is a relevant approach to quantify the expected gains or losses (i.e., the reward) associated with vaccinating a herd. Among the many existing models representing BVD virus spread within a cattle herd, a few focused on cow-calf herds [10,14-18]. Early, it has been shown that vaccination coverage has to be very high if PI animals are present [19]. The impact of vaccination in beef herds has been assessed in different farming settings (e.g., in the US: [17], in New Zealand: [18]), with contrasted issues. In New Zealand, for example, killed vaccines are used, which require up to three doses and does not provide a very high foetal protection [18]. In Europe, mostly inactivated vaccines are used, which induce immunity lasting from a few months to a year, and which provide a good foetal protection as long as vaccination is performed before pregnancy [11]. However, how vaccination impact varies in relation with herd characteristics is still barely known, while the practical application of existing tools has been highlighted as a crucial gap of knowledge [4], especially to determine effective ways to control BVD in different production systems. Thus, to produce practical conclusions, models should account for the specificities of the farming systems. This is particularly important for BVD in beef herds because these herds often have a seasonal calving and are exposed to infection at pasture, both being concomitant. In France, several beef farming systems coexist, most with a small to moderate herd size, in which BVD virus circulates and where vaccination impact is hardly quantified.

Our objective was to assess the economic impact of BVD and the reward associated with vaccination against BVD in French beef cow-calf herds, taking into account the characteristics of the farming systems the most commonly encountered in France, as well as the external risk of virus introduction due to proximity contacts and the characteristics of the vaccine. We adapted a mechanistic, partially individual-based, and stochastic epidemiological model of BVD virus spread at herd scale [10] to three farming systems representative of French cow-calf herds, named by their main breed: Charolaise, Blonde $\mathrm{d}$ 'Aquitaine, and Limousine. We included vaccination in the model to assess strategies defined by the type of protection conferred by the vaccine and the vaccine used. We calculated the yearly and the cumulative economic impact of BVD in these herds, and the expected reward associated with vaccination. Finally, we transformed this into a web decision support tool freely available to French cattle health managers.

\section{Material and Methods}

A stochastic partially individual-based model in discrete time was developed to represent BVD virus spread in a cow-calf herd and to assess the effectiveness of vaccinating breeding females, as usually recommended. A time interval of 7 days enables to properly represent transiently-infected animals in the infection process. The model without vaccination has been previously described [10]. Its main characteristics are briefly recalled hereafter, with a simplification of the computation of the transmission rate during the pasture period. The implementation of the vaccination strategy, new in the model, is described in details.

\subsection{Herd Dynamics}

Animals of the herd can be of seven types: calves from birth until weaning, male and female weaned calves for selling (grassers), heifers younger than 2 years kept for 
breeding, breeding heifers, cows from the first pregnancy diagnosis until fattening decision, cows from fattening decision until culling, and bulls. The herd management is seasonal, including breeding, calving, indoor and outdoor periods. During the indoor period, we assumed a homogeneous contact structure. The breeding period essentially occurs during the outdoor period. During the outdoor period, animals are on pastures, except remaining grassers which stay indoor until they are sold. Animals are grouped as following: (i) all young heifers, (ii) all breeding heifers plus bulls, and (iii) all calves and cows plus all remaining bulls. The herd size is determined by the number of heifers and cows kept for breeding which is constant for a scenario, so that the farmer can reach his production objective (expected number of animals for sale). In case of unexpected calf mortality or of numerous infertility/abortion events, the farmer purchase replacement calves or pregnant females, respectively. Grassers are sold during the course of the year, at one, two or three different dates. Females detected as empty at the beginning of the indoor period are sold 100 days later. Cows selected for fattening at the beginning of the breeding period are sold after the weaning of their calves.

The model was first parameterized for a Charolaise cow-calf herd structure (Figure 1), the main French beef farming system. Then, it was adapted to represent two other farming systems widespread in France, which main breeds are Limousine and Blonde d'Aquitaine. All the three breeds together constitute more than $60 \%$ of the French beef cows. In Limousine and Blonde d'Aquitaine, herds are smaller (respectively 68 and 66 females kept for breeding, against 90 in Charolaise). All the three systems sell their grassers in fall, except Charolaise female grassers sold in spring. The Charolaise system is also the only one to sell some heifers, while the two others keep all their heifers for breeding. In Charolaise, grazing period is the longest, animals on pasture being thus exposed to animals from neighbouring herds for a longer time period. Calf mortality is slightly higher in Charolaise and Blonde $\mathrm{d}^{\prime}$ Aquitaine, and weaning is earlier in Blonde d'Aquitaine (August) compared to Charolaise and Limousine (October). Table 1 provides parameter values for each of the three considered farming systems.

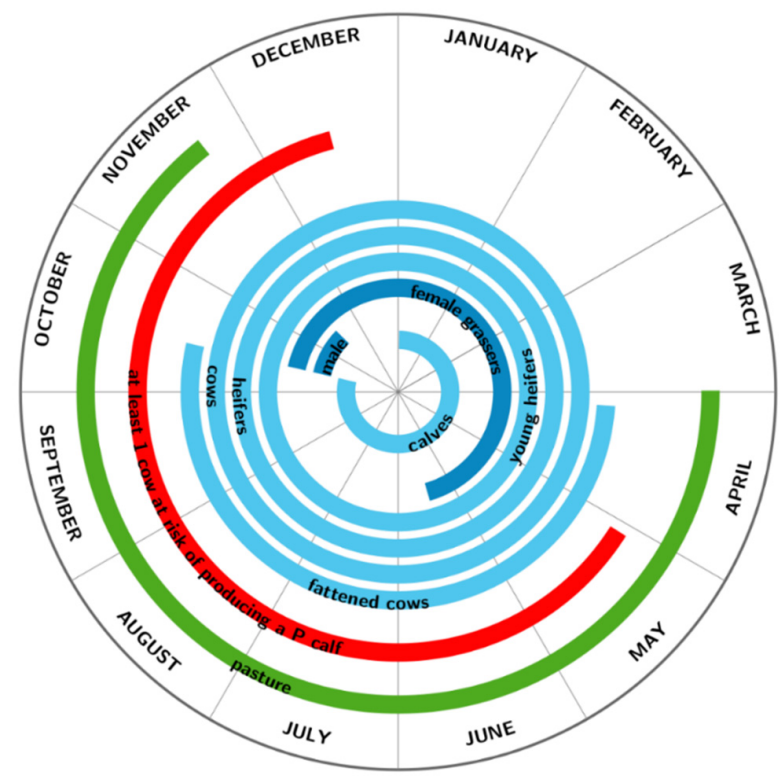

Figure 1. Calendar of the Charolaise farming system. The periods where each of the 7 animal groups are present in a cow-calf herd across a year are shown in blue. With a breeding period from end of March to end of July, the risk period is from start of May to mid-December, where cows can be in mid-pregnancy and vertical transmission is then highly probable if infection occurs. Animals can be in contact with infected neighbouring farms during the pasture period. Only male and female grassers are kept indoor. 
Table 1. Values of model parameters for the three farming systems.

\begin{tabular}{lccc}
\hline Parameters & Charolaise & Limousine & Blonde d'Aquitaine \\
\hline Number of cows kept for breeding & 68 & 56 & 53 \\
Number of heifers kept for breeding & 22 & 12 & 13 \\
Probability of infertility of cows & 0.061 & 0.048 & 0.080 \\
Probability of infertility of heifers & 0.039 & 0.026 & 0.058 \\
Probability of having twins & 0.023 & 0.05 & 0.022 \\
Probability of calf mortality before weaning & 0.08 & 1 October & 0.07 \\
Weaning date & 14 October & 4 February-4 June & 29 August \\
Breeding period & 22 March-19 July February-19 July \\
Pasture period & 1 April-22 November & 1 April-14 November & 10 April-9 November \\
Pasture length & 237 days & 229 days & 215 days \\
Sale period of male grassers & 15 November (+/-3 weeks) & 15 November (+/-3 weeks) \\
Sale period of female grassers & 15 June (+/-3 weeks) & 0 & 0 \\
Number of heifers sold at breeding & 2 & 0
\end{tabular}

\subsection{Within-Herd Infection Dynamics and Vaccination}

Animals are classified into mutually exclusive health states (Figure 2): susceptible $(\mathrm{S})$, transiently-infected $(\mathrm{T})$, recovered, i.e., immune (R), protected by maternal antibodies $(M)$, persistently infected $(P)$, vaccinated without loss of immunity $\left(V_{1}\right)$ or vaccinated with progressive loss of immunity $\left(V_{2}\right)$. The $M$ to $S$, $T$ to $R$, and $V_{2}$ to $S$ transitions depend on transition rates $\Phi_{\mathrm{MS}}, \Phi_{\mathrm{TR}}$, and $\Phi_{\mathrm{VS}}$ (Table 2). Since the duration of the maternal protection lasts generally 4-6 months [20], we assumed that the $M$ to $S$ transition occurs only in calves.

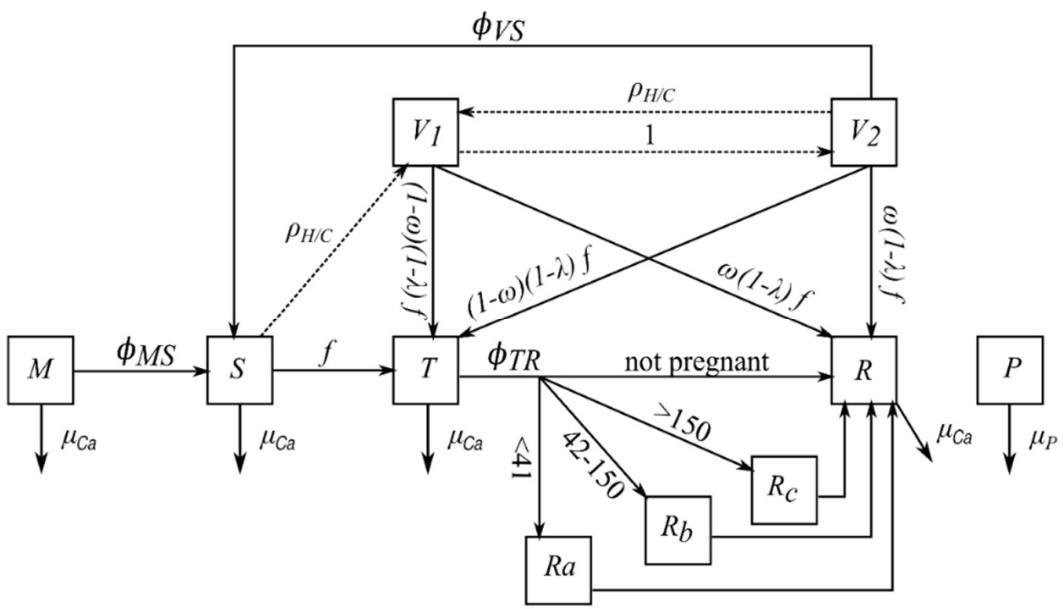

Figure 2. Transitions between health states. M: protected by maternal antibodies; S: susceptible; T: transiently infected; $P$ : persistently infected; $R$ : immune; $R_{a}, R_{b}, R_{c}$ : immune and pregnant, infected respectively in early, mid-, and late pregnancy; $V_{1}$ : vaccinated without loss of immunity; $\mathrm{V}_{2}$ : vaccinated with progressive loss of immunity. Symbols $\rho_{\mathrm{H} / \mathrm{C}}, \omega$ and $\lambda$ stand respectively for the vaccination of breeding heifers and cows (Boolean), the protection conferred by the vaccine against vertical transmission, and the protection conferred by the vaccine against infection. Health state $M$, mortality rate $\mu_{C a}$, and transition rate $\phi_{M S}$ only concern calves. Health states $R_{a}, R_{b}, R_{c}, V_{1}$ and $V_{2}$ only concern breeding heifers and cows. Transitions from $S$ to $V_{1}$ and from $V_{2}$ to $V_{1}$ occur once a year at the beginning of the breeding period $\left(\rho_{\mathrm{H} / \mathrm{C}}=1\right)$. Transition from $\mathrm{V}_{1}$ to $\mathrm{V}_{2}$ depends on the duration in state $V_{1}\left(\Delta_{V 1}\right)$. The force of infection $f$ is derived from Equations (1) and (2), other parameters are given in Tables 2 and 3.

As classically observed in the field, breeding females (breeding heifers and cows) are vaccinated when they are indoors and just before breeding. This provides the highest level of protection against the risk of birth of $\mathrm{P}$ calves. At the start of the breeding period, breeding females in states $S$ and $V_{2}$ go to state $V_{1}$ if vaccinated $\left(\rho_{H / C}=1\right)$. Other health states are not impacted by vaccination. The start of a progressive loss of immunity, i.e., 
the $V_{1}$ to $V_{2}$ transition, is defined by the duration in $V_{1}\left(\Delta_{V 1}\right)$, which is considered as constant and depends on the vaccine. Parameter $\lambda$ represents the ability of the vaccine to protect animals against infection (reduces the transition to state $\mathrm{T}$ ), while parameter $\omega$ defines the level of protection against vertical transmission if infected (Figure 2). When the vaccine is no longer effective, the animal becomes susceptible again (transition from $V_{2}$ to $S$, which depends on the mean duration in $V_{2}\left(\Delta_{V 2}\right)$, assuming an exponential distribution of the state duration). To account for the diversity of vaccines, parameter values are based on 4 commercial vaccines (Table 3): Bovilis ${ }^{\circledR}$ BVD-MD (Msd Animal Health, Madison, NJ, USA), Bovela ${ }^{\circledR}$ (Boehringer Ingelheim, Ingelheim, Germany), Rispoval ${ }^{\circledR}$ DBVD (Pfizer, New York, NY, USA), and Mucosiffa ${ }^{\circledR}$ (Merial, Lyon, France). For all vaccines, a protection of at least one year is guaranteed by vaccine producers, thus the duration in $V_{1}$ is assumed to be 52 weeks. The mean duration in $V_{2}$ is unknown, thus we keep it short not to assume a too long vaccine immunity. The level of protection against infection (horizontal transmission) is also unknown. Hence, we assume that infection can occur with the same probability as for susceptible animals, but with a reduced risk of vertical transmission. Infected animals all have a lifelong post-infection immunity. We assess also the opposite case (in a single scenario using Bovilis ${ }^{\circledR}$ ), i.e., vaccination protecting against infection. In that case, vaccinated animals are infected with a reduced probability compared to susceptible ones, but if infected, the risk of vertical transmission is similar. Most will not be infected, also meaning they will not develop post-infection immunity. All vaccines target BVD virus of type 1, which is the main one circulating in Europe [21]. We assume an average level of protection conferred by the vaccines, without explicitly accounting for the diversity of circulating virus sub-types and its impact on vaccine protection [22].

Table 2. Epidemiological parameters.

\begin{tabular}{|c|c|c|c|}
\hline Scheme & Definition & Value & Reference \\
\hline$\mu_{P, b i}$ & Probability of mortality at birth of P calves & 0.0667 & {$[7,23]$} \\
\hline$\mu_{\mathrm{Ca}, \mathrm{bi}}$ & Probability of mortality at birth of non-P calves & 0.02 & \\
\hline$\mu_{P}$ & Mortality of $\mathrm{P}$ animals per day & 0.0019 & {$[7,23]$} \\
\hline$\mu_{\mathrm{Ca}}$ & Mortality of non-P calves per day & 0.000326 & \\
\hline$\phi_{\mathrm{MS}}$ & Transition rate from state $\mathrm{M}$ to state $\mathrm{S}$ per day & 0.00667 & [24] \\
\hline$\phi_{\mathrm{TR}}$ & Transition rate from state $\mathrm{T}$ to state $\mathrm{R}$ per day & 0.2 & [25] \\
\hline$\phi_{\mathrm{VS}}$ & Transition rate from state $V_{2}$ to state $S$ per day & $1 / \Delta_{\mathrm{V} 2}$ & \\
\hline$\beta^{\mathrm{T}}$ & Transmission rate for $\mathrm{T}$ animals & 0.03 & {$[26,27]$} \\
\hline$\beta^{\mathrm{P}}$ & Transmission rate for $\mathrm{P}$ animals & 0.5 & {$[26,28]$} \\
\hline$\alpha_{\mathrm{Ra}}$ & Abortion rate due to infection early pregnancy & 0.8 & {$[6,25,29]$} \\
\hline$\alpha_{\mathrm{Rb}}$ & Abortion rate due to infection mid-pregnancy & 0.2 & {$[6,30,31]$} \\
\hline$\eta_{P}$ & Probability of giving birth to a calf in state $\mathrm{P}, \mathrm{M}$, or $\mathrm{R}$ & 0.9375 & \\
\hline$\eta_{M}=\eta_{R}$ & if infection in mid-pregnancy and no abortion & 0.03125 & {$[6,28,30-32]$} \\
\hline $\mathrm{K}_{\mathrm{ext}}$ & External risk of virus introduction during pasture & $0-0.001$ & \\
\hline
\end{tabular}

Table 3. Vaccine parameters.

\begin{tabular}{|c|c|c|c|c|c|}
\hline Scheme & Definition & Bovilis $^{\circledR}$ & Bovela $^{\circledR}$ & Rispoval $^{\circledR}$ & Mucosiffa $^{\circledR}$ \\
\hline$\rho_{\mathrm{H} / \mathrm{C}}$ & Boolean & \multicolumn{4}{|c|}{1 if vaccination, 0 otherwise } \\
\hline$\lambda$ & Probability of protection against infection ${ }^{£}$ & $0 / 1 *$ & 0 & 0 & 0 \\
\hline$\omega$ & Probability of protection against vertical transmission $\S$ & $1 / 0 *$ & 0.985 & 0.9 & 0.9 \\
\hline$\Delta_{\mathrm{V} 1}$ & Duration in $\mathrm{V}_{1}$ state (weeks) $\S$ & 52 & 52 & 52 & 52 \\
\hline$\Delta_{\mathrm{V} 2}$ & Duration in $\mathrm{V}_{2}$ state (weeks) ${ }^{£}$ & 8 & 8 & 8 & 8 \\
\hline$c_{D}$ & Dose cost (euro) $\S$ & 4.59 & 5.80 & 4.33 & 5.72 \\
\hline $\mathrm{n}_{1}$ & Number of vaccine doses for the first shot $\S$ & 2 & 1 & 2 & 1 \\
\hline $\mathrm{n}_{2}$ & Number of vaccine doses for the second shot $\S$ & 1 & 1 & 1 & 1 \\
\hline
\end{tabular}

${ }^{*}$ According to the type of protection considered. ${ }^{\S}$ Commercial information (vaccine producers, vet costs, etc.). ${ }^{£}$ Assumed. 
The force of infection $f$ depends on the repartition of the shedding animals (T, $\mathrm{P})$ in the herd. In winter (indoor period), animals are assumed to be all together, thus to be equally in contact with infected animals. The force of infection then is:

$$
\mathrm{f}=\beta^{\mathrm{P}} \frac{\mathrm{N}^{\mathrm{P}}}{\mathrm{N}}+\beta^{\mathrm{T}} \frac{\mathrm{N}^{\mathrm{T}}}{\mathrm{N}}
$$

with $\mathrm{N}^{\mathrm{P}}$ and $\mathrm{N}^{\mathrm{T}}$ the total number of $\mathrm{P}$ and $\mathrm{T}$ animals in the herd, respectively, $\mathrm{N}$ the herd size, and $\beta^{\mathrm{P}}$ and $\beta^{\mathrm{T}}$ the transmission rates per day associated with $\mathrm{P}$ and $\mathrm{T}$ animals, respectively (Table 2).

During the outdoor period, animals are split into separate pastures which do not share any contact. However, the virus can be introduced by contact with infected neighbouring farms. This external risk is modelled through a constant risk $K_{\text {ext }}$. The force of infection for susceptible animals in pasture $k$ is:

$$
f_{k}=\beta^{P} \frac{N_{k}^{P}}{N_{k}}+\beta^{T} \frac{N_{k}^{T}}{N_{k}}+K_{e x t}
$$

where $N_{k}^{P}$ and $N_{k}^{T}$ represent the total number of $\mathrm{P}$ and $\mathrm{T}$ animals in pasture $k$, respectively, and $N_{k}$ the number of animals in pasture $k$.

Transitions between health states are stochastic, using binomials. Specifically, the number of females changing from vaccinated state $V_{1}$ or $V_{2}$ to infected state $T$ or recovered state $\mathrm{R}$ state are calculated as:

$$
\begin{gathered}
\Delta N_{V T}=\operatorname{Bin}\left(N_{V},(1-\omega) p\right) \\
\Delta N_{V R}=\operatorname{Bin}\left(N_{V}, \omega p\right) \\
\text { with } p=1-e^{-\Delta t \lambda f}
\end{gathered}
$$

where $N_{V}$ is the number of vaccinated females (either in $V_{1}$ or in $V_{2}$ ), and $\Delta t$ the time step (7 days).

Several consequences including vertical transmission are modelled for infected-pregnant cows, according to the stage of pregnancy at infection time [6]. It is handled by an individual monitoring of breeding females (breeding heifers and cows). Females infected in early (0-41 days), mid-pregnancy (42-150 days), and late (151-285 days) pregnancy are in states $\mathrm{R}_{\mathrm{a}}$, $R_{b}$ or $R_{c}$, respectively, until calving (Figure 2). Embryonic or foetal deaths are assumed to be highly probable after infection in early or mid-pregnancy (Table 2), after which females join state R. On the contrary, infection occurring in late pregnancy leads to the birth of R calves. When infection occurs in mid-pregnancy, vertical transmission leading to the birth of a P calf is assumed to be highly probable. Vaccinated females are assumed to give birth to calves protected by maternal antibodies (state $\mathrm{M}$ ).

Finally, calf mortality depends on health state. Non-P calves have a mortality rate $\mu_{\mathrm{Ca}}$ between birth and weaning, while $\mathrm{P}$ animals have a disease-related mortality $\mu_{\mathrm{P}}$ all their life. $\mathrm{P}$ and non-P calves also have a probability of dying at birth, $\mu_{\mathrm{P}, \mathrm{bi}}$ and $\mu_{\mathrm{Ca}, \mathrm{bi}}$ respectively (Table 2 ).

\subsection{Model Outputs}

The model predicts BVD impact and the vaccination reward in euros per euro invested per cow per year. For each farming system, the meat value, the weight on sale (based on the periods of calving and sale), and the average production cost per $\mathrm{kg}$ of meat produced are known (Table 4). 
Table 4. Weight and price of sold and purchased animals. Parameter values depend on the farming systems, based on data from Inosys Réseaux d'élevage (2014, https:/ / idele.fr/detail-dossier/cas-types-bovins-allaitants (accessed on 4 October 2020)).

\begin{tabular}{|c|c|c|c|c|c|c|c|}
\hline \multicolumn{2}{|c|}{ Parameters } & \multicolumn{2}{|c|}{ Charolaise } & \multicolumn{2}{|c|}{ Limousine } & \multicolumn{2}{|c|}{ Blonde d'Aquitaine } \\
\hline & & $€$ & Kg & $€$ & Kg & $€$ & Kg \\
\hline \multirow{7}{*}{$\begin{array}{c}\text { Price and weight per } \\
\text { animal type }\end{array}$} & Replacement calf & 352 & 47 & 352 & 42 & 352 & 46 \\
\hline & Gestating cow & 1689 & 747 & 1621 & 682 & 1828 & 814 \\
\hline & Male grasser & 1051 & 420 & 966 & 315 & 915 & 260 \\
\hline & $\begin{array}{l}\text { Female grasser } \\
\text { (sold in fall) }\end{array}$ & - & - & 793 & 300 & 724 & 240 \\
\hline & $\begin{array}{l}\text { Female grasser } \\
\text { (sold in spring) }\end{array}$ & 985 & 400 & - & - & - & - \\
\hline & Fattened heifer & 1330 & 630 & - & - & - & - \\
\hline & Culled cow & 1337 & 700 & 1570 & 691 & 1710 & 798 \\
\hline $\mathrm{C}_{\text {prod }}$ & Production cost per $\mathrm{kg}$ & 0.754 & - & 0.652 & - & 0.775 & - \\
\hline
\end{tabular}

From these prices, weights, production costs and model outputs (i.e., number of animals sold and purchased per group), we calculate the approximate earnings before interest and taxes, which provides an economic measure of the income loss for livestock producers. It accounts for the difference of price between sales and purchases, as well as for the variation in herd size and thus in production cost. The calculation of production cost of animals neither bought nor sold is not necessary since it is considered similar in all situations.

The approximate earnings before interest and taxes are:

$$
E=\sum_{i \in S a} N_{i} c_{i}-\sum_{i \in P u} N_{i} c_{i}-C_{\text {prod }}\left(\sum_{i \in S a} N_{i} k_{i}-\sum_{i \in P u} N_{i} k_{i}\right)
$$

with $\mathrm{Sa}=$ \{grassers, fattened heifers, culled cows $\}, \mathrm{Pu}=$ \{replacement calves, gestating cows $\}, C_{\text {prod }}$ the production cost per kg specific to each farming system (Table 4 ), $\mathrm{N}_{\mathrm{i}}$ the number of animals in group $i, c_{i}$ the price (in $€$ ) of an animal of group $i$, and $k_{i}$ the weight (in $\mathrm{kg}$ ) of an animal of group $\mathrm{i}$.

Then, the BVD impact (I) is:

$$
I=E_{B V D V}-E_{\varnothing B V D V}
$$

with $E_{B V D V}$ and $E_{\varnothing B V D V}$ the earnings with and without BVD virus spread respectively. Impact thus is negative. However, due to stochastic events, pairs of repetitions with and without BVD spreading cannot be directly compared. We sorted repetitions in order to associate $E_{B V D V}$ and $E_{\varnothing \mathrm{BVDV}}$ of similar ranking. Nevertheless, impacts still can be positive. In such a case, we considered them as nil. The expected vaccination reward is:

$$
R=I_{\text {vacc }}-C-I_{\varnothing v a c c}
$$

with $C$ the vaccination cost, and $I_{\text {vacc }}$ and $I_{\varnothing v a c c}$ the BVD impacts with and without vaccination, respectively. The vaccination cost depends on the vaccine characteristics (price and number of doses required; Table 3), as well as on the number of females vaccinated, i.e., the number of breeding heifers and cows which is constant. An average cost is estimated based on the number of doses administered, knowing that for a first vaccination (for heifers) the doses can be higher:

$$
C=\frac{\left(N_{H}+N_{C}\right) \rho_{H / C} n_{1} c_{D}+\left(N_{H} n_{1}+N_{C} n_{2}\right) \rho_{H / C} c_{D}(y-1)}{y}
$$

with $\mathrm{N}_{\mathrm{H}}$ and $\mathrm{N}_{\mathrm{C}}$ the number of breeding heifers and cows, respectively, $\rho_{\mathrm{H} / \mathrm{C}}$ the boolean indicating if there is vaccination (Table 3 ), $\mathrm{n}_{1}$ and $\mathrm{n}_{2}$ the number of vaccine doses for the 
first shot and for the following ones respectively, $c_{D}$ the cost of a vaccine dose, and $y$ the number of years of vaccination. The first year, all breeding females are assumed to be at their first shot. Finally, the euros per euro invested per cow per year is:

$$
E i=\frac{R_{\text {cumul }}}{N_{y} C}
$$

with $R_{\text {cumul }}$ the cumulated reward over the simulated years, $\mathrm{N}_{\mathrm{y}}$ the number of simulated years, and $C$ the average vaccination cost per year. This output has the advantage of combining the information associated with disease losses, vaccination cost, and reward.

The model was developed in $\mathrm{C}++$ and Python, and is available under Apache 2 License here: https: / / forgemia.inra.fr/sandie.arnoux/bvd-within-herd-model-public (accessed on 4 October 2020). It has been adapted as a tool for French animal health managers (in French), EvalBVD (https: / / mihmestools.eu/evalbvd/home/ (accessed on 4 October 2020)). It corresponds to a freely available web interface, where all the parameters related to the farming system and the vaccination strategy can be set to represent a specific situation.

\subsection{Simulation Settings}

The expected number of $\mathrm{P}$ calf births in a BVD-free herd exposed to a given external risk $K_{\text {ext }}$ is:

$$
\left(1-\left(1-K_{e x t}\right)^{\frac{W}{2}}\right)\left(1-\alpha_{R b}\right) \eta_{P} N_{F} \Delta_{t}
$$

where $K_{\text {ext }}$ is the external risk, $W$ the number of weeks on pasture, $\alpha \mathrm{Rb}$ the abortion rate due to infection mid-pregnancy, $\eta_{\mathrm{P}}$ the probability of giving birth to a calf in state $\mathrm{P}$ after infection in mid-pregnancy and if no abortion, $\mathrm{N}_{\mathrm{F}}$ the number of breeding females, and $\Delta \mathrm{t}$ the time interval. $\left(1-\mathrm{K}_{\text {ext }}\right)^{\wedge}(\mathrm{W} / 2)$ is the probability not to be infected in mid-gestation on pasture. Using Equation (11), 0.4, 1.9, and 7.7 P calf births are expected if the BVD virus is introduced in a naïve Charolaise herd $\left(\mathrm{W}=33\right.$ weeks, $\left.\mathrm{N}_{\mathrm{F}}=90\right)$ exposed to $\mathrm{K}_{\mathrm{ext}}=0.00005$, 0.00025 , and 0.001 , respectively.

A reference scenario considers a BVD-free Charolaise herd consistently exposed outdoor to an external risk $\mathrm{K}_{\text {ext }}$ of 0.00025 over an 8-year period. We compared results without and with vaccination of all breeding heifers and cows with the vaccine Bovilis ${ }^{\circledR}$.

We also tested complementary scenarios, modifying part of the settings of this reference scenario. First, we compared the efficiency of four commercial vaccines (Table 3) under a large range of $K_{\text {ext }}$ values (from 0 to 0.001). Second, we compared the three farming systems (Charolaise, Limousine and Blonde d'Aquitaine) under two $\mathrm{K}_{\text {ext }}$ values (one moderate 0.00025 and one high 0.001 ). To reduce computational costs and because the largest losses due to BVD in beef cow-calf herds are known to occur in the first few years after virus introduction, we simulated 5 years for all these scenarios.

Finally, we assessed the effect of stopping vaccination in a Charolaise herd, using Bovilis ${ }^{\circledR}$, and for a large range of $K_{\text {ext }}$ values (from 0 to 0.001 ). The scenario was explored over 20 years: vaccination was implemented the first 6 years, and then stopped. We considered two contrasted protections conferred to vaccinated animals: no infection $(\lambda=1$ and $\omega=0)$ versus no vertical transmission if infected $(\lambda=0$ and $\omega=1)$. For each scenario, we ran 1000 repetitions to ensure model output stability.

\subsection{Sensitivity Analysis}

Vaccination reward is computed from BVD impact and vaccination cost. Therefore, reward and impact are highly correlated. Thus, we limited the sensitivity analysis of the model to BVD impact. We varied simultaneously all epidemiological parameters by plus or minus $25 \%$ of their nominal values. A complete factorial design [33] was used to estimate the sensitivity indices related to the principal effect and to interactions between parameters for each of the parameter tested, $\mu_{P, b i}, \mu_{P}, \beta^{P}, \beta^{T}, \Phi_{M S}, \Phi_{T R}, \alpha_{R a}, \alpha_{R b}$ and $\eta_{P}$. To limit the number of simulations, closely related parameters were grouped $\left(\beta^{\mathrm{P}}\right.$ and $\beta^{\mathrm{T}}, \Phi_{\mathrm{MS}}$ and $\Phi_{\mathrm{TR}}$, 
$\alpha_{\mathrm{Rb}}$ and $\left.\eta_{\mathrm{P}}\right)$ and thus varied in the same direction at the same time. A total of 729 scenarios were run, with 1000 repetitions per scenario.

\section{Results}

\subsection{BVD Impact and Vaccination Reward in Exposed Beef Cow-Calf Herds of Charolaise System}

In a naive cow-calf herd in the Charolaise breeding system, the greatest BVD impact occurred on average 3 years after the herd began to be exposed to the virus due to close contact with infected farms (Figure 3). Over five and eight years, it reached $113 €$ and $163 €$ per cow, respectively. If vaccination started immediately (i.e., when exposure started), the associated reward was positive from years 3 to 5, when the BVD impact was high. The rest of the time, the vaccination cost per year overpassed the BVD impact per year, either because consequences due to infection were not already visible (year 1 and 2) or because of herd immunity which has developed after the natural infection has occurred (year 6 and after). Nevertheless, the median reward per year over the whole period was positive. It was $0.80 €$ per invested euro per vaccinated animal per year over the first five years (percentiles $25 / 75$ being $0.21 / 1.40 €$ ).

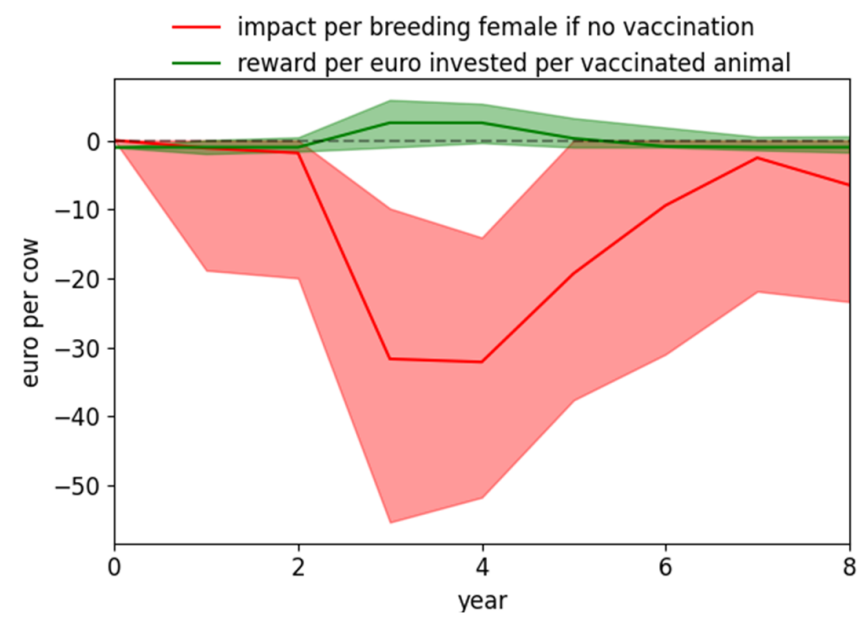

Figure 3. BVD impact and reward after vaccination (in $€$ per breeding female). A beef cow-calf herd of Charolaise breeding system is exposed to a moderate external risk of virus introduction $\left(K_{\text {ext }}=0.00025\right)$. The Bovilis ${ }^{\circledR}$ vaccine is provided yearly to all breeding females before the start of the breeding period. The envelop shows the percentiles 25 and 75 of the 1000 stochastic repetitions for both scenarios.

\subsection{Influence of the Vaccine Used and of the External Risk of Virus Introduction}

Irrespective of the vaccine used, vaccination was beneficial when the external risk exceeded the threshold of $7 \times 10^{-5}$, which corresponds to one new $\mathrm{P}$ calf born on average every two years in a fully susceptible herd (Figure 4). Then, for an external risk of 0.00025 , the reward over the first five years increased up to $0.85 €$ per invested euro per year and per vaccinated animal. An external risk of 0.00025 corresponds to two persistently infected calves born on average over a pasture period in an exposed naive herd. A plateau was reached: the reward did not increase further for higher values of the external risk. It has to be noted the extreme variability of the reward for a given external risk: it varied from $-3 €$ to $+4 €$ per invested euro if the external risk was at least moderate, the variations occurring among repetitions of a given scenario, thus related to the model stochasticity and the occurrence of quite rare events such as the birth of a P calf, or on the contrary its death quickly after birth. 


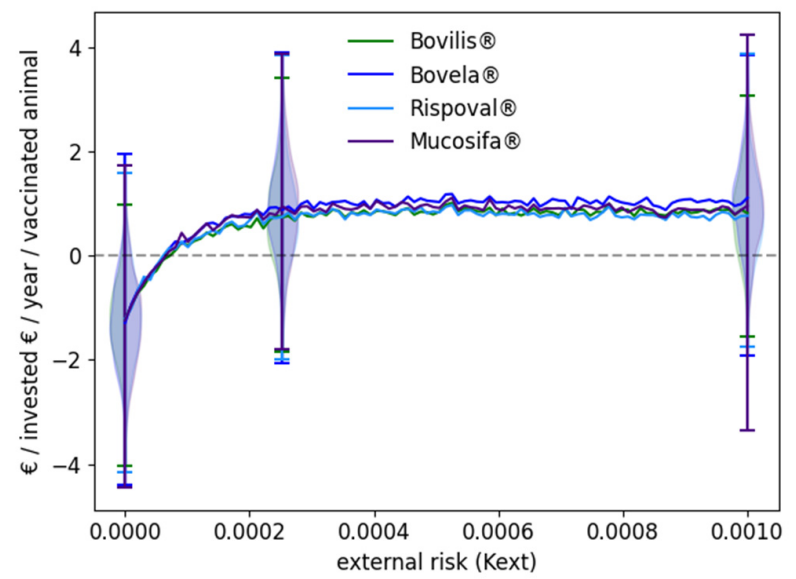

Figure 4. Reward after vaccination against BVD according to the vaccine used and the external risk of virus introduction. A beef cow-calf herd of Charolaise breeding system is considered. All breeding females are vaccinated yearly before the start of the breeding period using one of four commercial vaccines (see Table 1 for details on vaccines). The curves show the median over 1000 stochastic repetitions of the euros obtained per euro invested per year per vaccinated animal over 5 years according to the external risk. The violin plots show the values for the 1000 stochastic repetitions for three $\mathrm{K}_{\text {ext }}$ : 0, 0.00025, 0.001. Each side of the violin plots shows two overlapping scenarios: Bovilis ${ }^{\circledR}$ and Bovela ${ }^{\circledR}$ on the left; Rispoval ${ }^{\circledR}$ and Mucosiffa ${ }^{\circledR}$ on the right.

\subsection{Comparison of Three French Farming Systems}

While vaccination is not beneficial for all external risks, it is also not beneficial for all farming systems (Figure 5). The reward highly varied for a given situation (farming system $x$ external risk), being positive in more than $75 \%$ of the cases in Charolaise if the external risk was higher than 0.00025. For the two other farming systems, Limousine and Blonde d'Aquitaine, the reward was predicted to be positive in half the cases and negative in the other half, even for large external risks. As a result, and in contrast to Charolaise, the median reward was almost nil in Blonde d'Aquitaine and Limousine (percentiles 25/75 being $-0.80 / 0.35 €$, and $-0.72 / 0.37 €$, respectively).

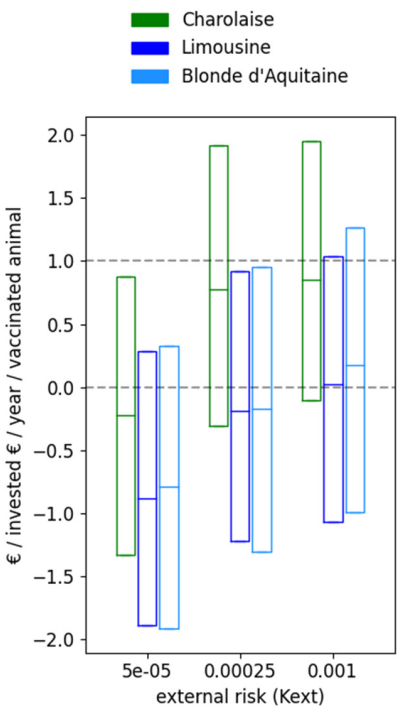

Figure 5. Return on investment after vaccination against BVD according to the farming system and the external risk of virus introduction. All breeding females are vaccinated yearly before the start of the breeding period using Bovilis ${ }^{\circledR}$. Three farming systems are compared: Charolaise, Limousine and Blonde d'Aquitaine. The percentiles 10, 50 and 90 of the euros per euro invested per year per vaccinated animal over 5 years are shown from 1000 stochastic repetitions. 


\subsection{When to Stop Vaccinating?}

In Charolaise, for a moderate external risk and if this risk has not been decreased, stopping vaccinating was not relevant even if the reward was predicted to be negative after six years (Figure 6). Indeed, a few years after stopping vaccinating breeding females, herd immunity becomes sufficiently low and the same situation occurs again (brown and orange curves in Figure 6).

--- impact per bred female if no vaccination

--- reward per euro invested per vaccinated animal if non-stop vaccination

_ impact per bred female after protection against vertical transmission

_ impact per bred female after protection against infection

\section{A}

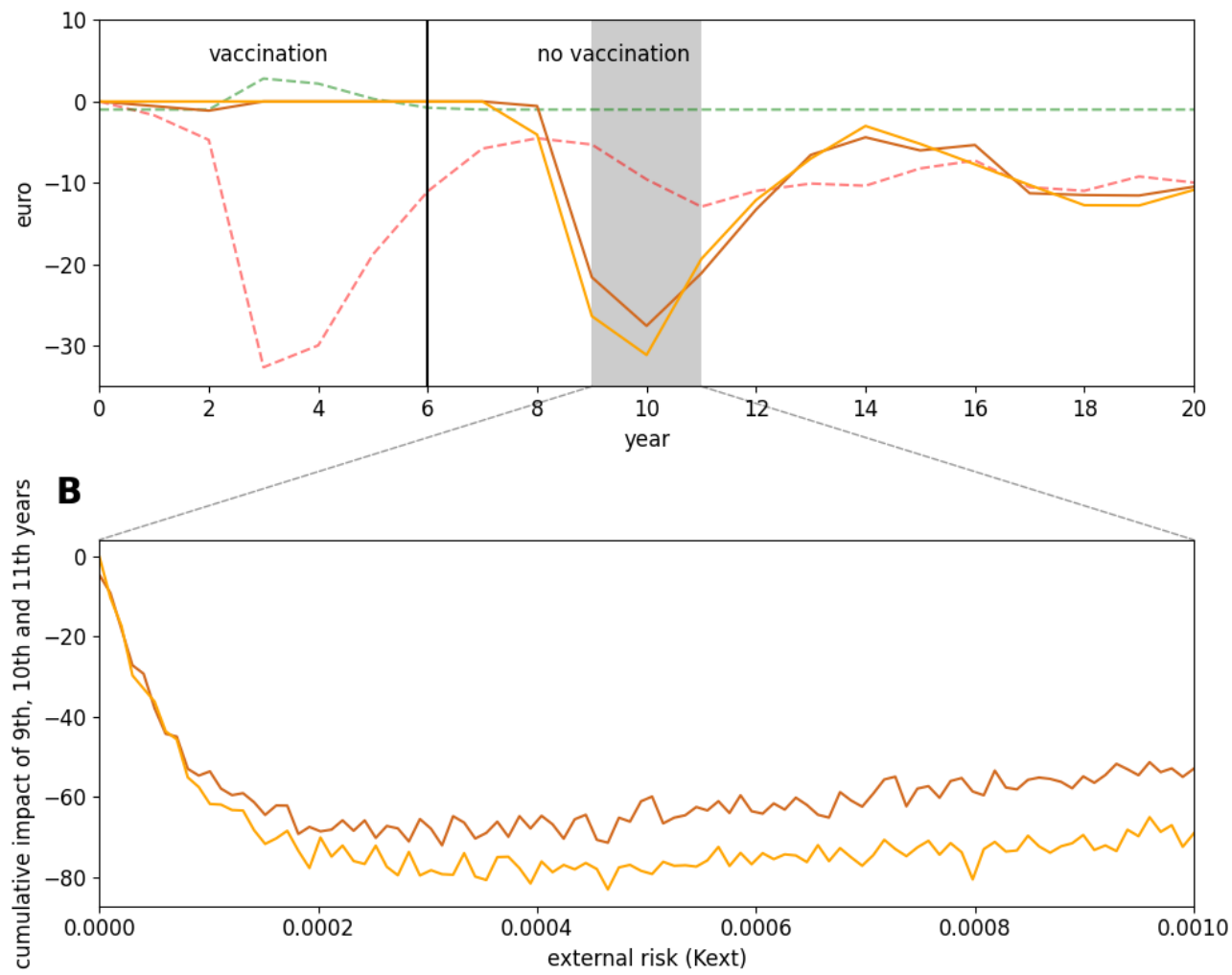

Figure 6. BVD impact and vaccination reward according to the type of protection conferred by the vaccine. A beef cow-calf herd of the Charolaise breeding system is considered. In scenarios with vaccination, all breeding females are vaccinated yearly with Bovilis ${ }^{\circledR}$ before the start of the breeding period. Vaccination is stopped after 6 years and 2 types of protection are tested: against vertical transmission and against infection. (A): BVD impact per breeding female and reward per euro invested per vaccinated animal when assuming a moderate external risk $\left(\mathrm{K}_{\mathrm{ext}}=0.00025\right)$; (B): Cumulative BVD impact per breeding female over three years (years 9, 10 and 11) according to the external risk. In all cases, the median over 1000 stochastic repetitions is shown.

Similar results were obtained when assuming the vaccine fully protects against infection (animals becoming susceptible again once vaccine immunity has faded out) or when assuming the vaccine only protects against vertical transmission (thus infection can occur-and animals then become immune for life-but no P calf can be born). As expected, the second option reduced the BVD impact after vaccination has stopped, as more animals are immune in that situation, but the reward difference between the two types of protection was small. 


\subsection{Sensitivity of BVD Impact and Vaccination Reward to Epidemiological Parameters}

Varying the epidemiological parameters by $25 \%$ of their nominal values in a beef cow-calf herd of Charolaise breeding system exposed to a moderate external risk of virus introduction $\left(\mathrm{K}_{\mathrm{ext}}=0.00025\right)$ induced a variation of the median BVD impact, which ranged between -136 and $-87 €$ per breeding female. Most of this variation $(70 \%)$ was explained by the consequences of infection occurring during female pregnancy, especially during its early stage, the infection-related abortion rate in early pregnancy explaining half the variance of this model output (Figure 7). More surprisingly, the mortality rate of $\mathrm{P}$ animals and the transmission rates barely contributed to the variation of the BVD impact. No interaction between parameters contributed to explain output variations.

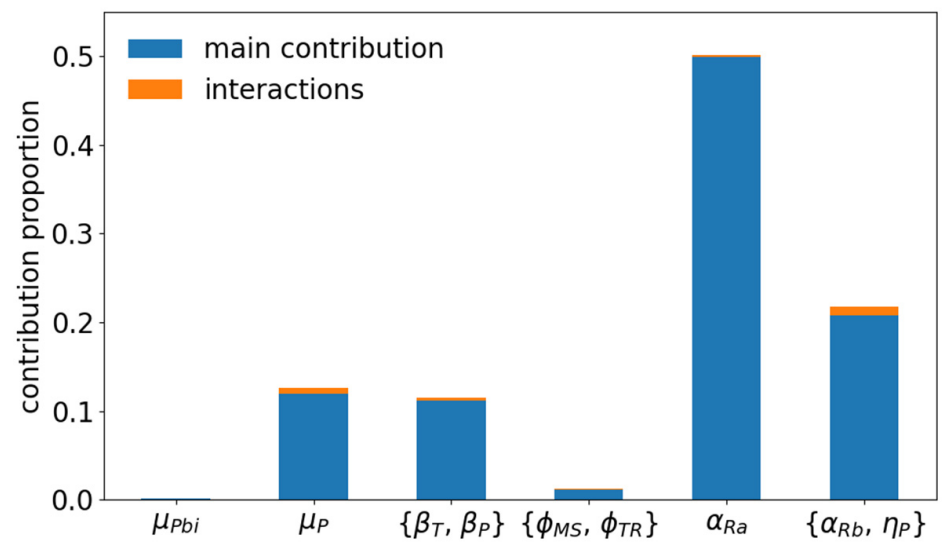

Figure 7. Sensitivity of BVD impact to variations in epidemiological parameters $( \pm 25 \%)$, using a complete factorial design. A beef cow-calf herd of the Charolaise breeding system is considered. Parameters are from left to right: mortality of $\mathrm{P}$ calves at birth, mortality of all $\mathrm{P}$ animals, transmission rates, transition rates between health states other than infection, abortion rate in early pregnancy, other consequences of infection during pregnancy.

\section{Discussion}

The results of our study highlight the importance of accounting for herd specificities to estimate BVD impact on beef cow-calf herd production and to assess vaccination efficiency to reduce this impact locally at herd scale. While BVD has an impact in Charolaise breeding system, irrespective of the commercial vaccine used and as long as the external risk was high enough, the median reward was almost nil in Blonde d'Aquitaine and Limousine breeding systems. This emphasises the large influence the farming system can have on BVD impact and on vaccination added value. French beef cow-calf seasonal herds are quite representative of other farming systems used in Europe (e.g., in Ireland: [34]). Although the three farming systems studied here could be considered as having quite similar management, the differences in the estimated BVD impact clearly indicate the need for looking specifically to BVD impact and vaccination reward for each farming system and not to extrapolate from results obtained with other farm settings. This strengthens the need for practical decision support tools to provide farmers and their advisers with estimations of BVD impact, and to guide farmers' decision on BVD vaccination. Accounting for the precise situation of the farm in terms of exposure to BVD virus introduction and of herd management is crucial, such as done in the EvalBVD tool.

When vaccination is effective, we showed that it is better not to stop vaccinating as long as the risk of BVD virus introduction due to proximity contacts with neighbouring herds has not been decreased. This is an important and practical finding for farmers, as the decision to stop controlling can be as hard to take as the decision to start. Indeed, BVD impact seems better explained by abortions than by the death of PI calves, as also found in the US [17]. Herd immunity does not last long enough to protect the herd over long period 
if vaccination is stopped. This is partly because of the herd renewal rate, partly because of the rather short duration of the individual immunity conferred by vaccination.

It emphasises the relevance of regional collective control strategies aiming at reducing BVD exposure at a larger scale than the single herd, using vaccination on such larger scale combined with the test-and-cull of persistently infected animals [35]. However, these collective strategies sometimes cannot be associated with vaccination, when serological tests are performed, as inactivated vaccines interfere with these tests [36]. In any case, it remains difficult to estimate the risk of BVD introduction by proximity contacts, and thus to assess its variation over time and with control implementation. This might impair the assessment of the efficiency of within-herd control measures, such as vaccination. Comparing costs and benefits of vaccination versus PCR testing to identify and remove persistently infected animals, analyses carried out in the Swiss eradication context show a return on investment of four years with individual testing [37]. Combining compulsory vaccination and testing also appears as efficient [12]. However, vaccination alone does not enable achieving eradication. It induces permanent costs that at best reduces losses below the cost of vaccination. In contrast, eradication, once reached, reduces control costs to that of herd serological surveillance, which is very moderate compared to disease costs and to vaccination costs. It should also be noted that $\mathrm{PCR}$ costs have largely decreased in recent years, e.g., being now in France in the order of 3-4€ per animal tested.

The present study considered only the BVD virus of type 1, the main one circulating in France [38]. Also, we neglected the diversity in co-circulating strains, while virus subtypes are numerous $[39,40]$ and vaccines does not protect against all of them [22]. This may further impair vaccination efficiency. It is an interesting modelling perspective: a multi-strain model would for example enable to assess the reward expected from using a multivalent vaccine and cross-protection against diverse virus sub-types.

We have highlighted that vaccination reward highly depends on the epidemiological situation and the farming system, but also varies within a given situation. The reward heterogeneity possibly explains why farmers' decisions with regards to BVD control are so heterogeneous in the field. To better account for the strategic behaviour of farmers and assess collective control scheme at large scale, there is a need for models combining farmers' decisions and the dynamics of the epidemiological situation [41].

Author Contributions: Conceptualization, S.A. (Sandie Arnoux), E.P., S.A. (Sébastien Assié) and P.E.; Data curation, F.B.; Formal analysis, S.A. (Sandie Arnoux) and P.E.; Funding acquisition, P.E.; Investigation, S.A. (Sandie Arnoux), F.B., A.D., E.P., S.A. (Sébastien Assié) and P.E.; Methodology, S.A. (Sandie Arnoux), A.D. and P.E.; Project administration, P.E.; Software, S.A. (Sandie Arnoux) and A.D.; Supervision, S.A. (Sébastien Assié) and P.E.; Validation, S.A. (Sandie Arnoux), F.B., E.P., S.A. (Sébastien Assié) and P.E.; Visualization, S.A. (Sandie Arnoux) and P.E.; Writing—original draft, S.A. (Sandie Arnoux) and P.E.; Writing-review \& editing, F.B., A.D., E.P. and S.A. (Sébastien Assié). All authors have read and agreed to the published version of the manuscript.

Funding: The French Research Agency (ANR), Program Investments for the Future, project ANR-10BINF-07 (MIHMES), the European fund for the regional development (FEDER Pays-de-la-Loire), the European Union's Horizon 2020 research and innovation programme under grant agreement No. 101000494 (DECIDE), and INRAE are acknowledged for providing financial support. This work was performed using HPC resources from GENCI-[CINES/IDRIS/TGCC](Grant 2021-[A0100312468]).

Data Availability Statement: The code is available under Apache 2 License at https: / forgemia.inra. $\mathrm{fr}$ /sandie.arnoux/bvd-within-herd-model-public (accessed on 4 October 2020).

Conflicts of Interest: The authors declare no conflict of interest. The funders had no role in the design, execution, interpretation, or writing of the study. 


\section{References}

1. Pinior, B.; Firth, C.L.; Richter, V.; Lebl, K.; Trauffler, M.; Dzieciol, M.; Hutter, S.E.; Burgstaller, J.; Obritzhauser, W.; Winter, P.; et al. A Systematic Review of Financial and Economic Assessments of Bovine Viral Diarrhea Virus (BVDV) Prevention and Mitigation Activities Worldwide. Prev. Vet. Med. 2017, 137, 77-92. [CrossRef] [PubMed]

2. Gates, M.C.; Humphry, R.W.; Gunn, G.J. Associations between Bovine Viral Diarrhoea Virus (BVDV) Seropositivity and Performance Indicators in Beef Suckler and Dairy Herds. Vet. J. 2013, 198, 631-637. [CrossRef] [PubMed]

3. Richter, V.; Kattwinkel, E.; Firth, C.L.; Marschik, T.; Dangelmaier, M.; Trauffler, M.; Obritzhauser, W.; Baumgartner, W.; Käsbohrer, A.; Pinior, B. Mapping the Global Prevalence of Bovine Viral Diarrhoea Virus Infection and Its Associated Mitigation Programme. Vet. Rec. 2019, 184, 711. [CrossRef] [PubMed]

4. Evans, C.A.; Pinior, B.; Larska, M.; Graham, D.; Schweizer, M.; Guidarini, C.; Decaro, N.; Ridpath, J.; Gates, M.C. Global Knowledge Gaps in the Prevention and Control of Bovine Viral Diarrhoea (BVD) Virus. Transbound. Emerg. Dis. 2019, 66, 640-652. [CrossRef]

5. Brownlie, J.; Clarke, M.C.; Howard, C.J.; Pocock, D.H. Pathogenesis and Epidemiology of Bovine Virus Diarrhoea Virus Infection of Cattle. Ann. Vet. Res. 1987, 18, 157-166.

6. Fray, M.D.; Paton, D.J.; Alenius, S. The Effects of Bovine Viral Diarrhoea Virus on Cattle Reproduction in Relation to Disease Control. Anim. Reprod. Sci. 2000, 60, 615-627. [CrossRef]

7. Houe, H. Survivorship of Animals Persistently Infected with Bovine Virus Diarrhoea Virus (BVDV). Prev. Vet. Med. 1993, 15, 275-283. [CrossRef]

8. Gates, M.C.; Woolhouse, M.E.J.; Gunn, G.J.; Humphry, R.W. Relative Associations of Cattle Movements, Local Spread, and Biosecurity with Bovine Viral Diarrhoea Virus (BVDV) Seropositivity in Beef and Dairy Herds. Prev. Vet. Med. 2013, 112, 285-295. [CrossRef]

9. Graham, D.A.; Clegg, T.A.; Thulke, H.H.; O'Sullivan, P.; McGrath, G.; More, S.J. Quantifying the Risk of Spread of Bovine Viral Diarrhoea Virus (BVDV) between Contiguous Herds in Ireland. Prev. Vet. Med. 2016, 126, 30-38. [CrossRef]

10. Damman, A.; Viet, A.-F.; Arnoux, S.; Guerrier-Chatellet, M.C.; Petit, E.; Ezanno, P. Modeling the Spread of Bovine Viral Diarrhea Virus (BVDV) in a Beef Cattle Herd and Its Impact on Herd Productivity. Vet. Res. 2015, 46. [CrossRef]

11. Moennig, V.; Becher, P. Control of Bovine Viral Diarrhea. Pathogens 2018, 7, 29. [CrossRef]

12. Gethmann, J.; Probst, C.; Bassett, J.; Blunk, P.; Hövel, P.; Conraths, F.J. An Epidemiological and Economic Simulation Model to Evaluate Strategies for the Control of Bovine Virus Diarrhea in Germany. Front. Vet. Sci. 2019, 6, 406. [CrossRef]

13. Iotti, B.; Valdano, E.; Savini, L.; Candeloro, L.; Giovannini, A.; Rosati, S.; Colizza, V.; Giacobini, M. Farm Productive Contexts and the Dynamics of Bovine Viral Diarrhea (BVD) Transmission. Prev. Vet. Med. 2019, 165, 23-33. [CrossRef] [PubMed]

14. Gunn, G.J.; Stott, A.W.; Humphry, R.W. Modelling and Costing BVD Outbreaks in Beef Herds. Vet. J. 2004, 167, 143-149. [CrossRef]

15. Stott, A.W.; Lloyd, J.; Humphry, R.W.; Gunn, G.J. A Linear Programming Approach to Estimate the Economic Impact of Bovine Viral Diarrhoea (BVD) at the Whole-Farm Level in Scotland. Prev. Vet. Med. 2003, 59, 51-66. [CrossRef]

16. Smith, R.L.; Sanderson, M.W.; Renter, D.G.; Larson, R.; White, B. A Stochastic Risk-Analysis Model for the Spread of Bovine Viral Diarrhea Virus after Introduction to Naive Cow-Calf Herds. Prev. Vet. Med. 2010, 95, 86-98. [CrossRef] [PubMed]

17. Smith, R.L.; Sanderson, M.W.; Jones, R.; N'Guessan, Y.; Renter, D.; Larson, R.; White, B.J. Economic Risk Analysis Model for Bovine Viral Diarrhea Virus Biosecurity in Cow-Calf Herds. Prev. Vet. Med. 2014, 113, 492-503. [CrossRef] [PubMed]

18. Han, J.-H.; Weston, J.F.; Heuer, C.; Gates, M.C. Modelling the Economics of Bovine Viral Diarrhoea Virus Control in Pastoral Dairy and Beef Cattle Herds. Prev. Vet. Med. 2020, 182. [CrossRef]

19. Cherry, B.R.; Reeves, M.J.; Smith, G. Evaluation of Bovine Viral Diarrhoea Virus Control Using a Mathematical Model of Infection Dynamics. Prev. Vet. Med. 1998, 33, 91-108. [CrossRef]

20. Lindberg, A. Bovine Viral Diarrhoea Virus Infections and Its Control: A Review. Vet. Q. 2003, 25, 1-16. [CrossRef]

21. Yesilbag, K.; Alpay, G.; Becher, P. Variability and Global Distribution of Subgenotypes of Bovine Viral Diarrhea Virus. Viruses 2017, 9, 128. [CrossRef]

22. Sozzi, E.; Righi, C.; Boldini, M.; Bazzucchi, M.; Pezzoni, G.; Gradassi, M.; Petrini, S.; Lelli, D.; Ventura, G.; Pierini, I.; et al. Cross-Reactivity Antibody Response after Vaccination with Modified Live and Killed Bovine Viral Diarrhea Virus (BVD) Vaccines. Vaccines 2020, 8, 374. [CrossRef]

23. Duffell, S.; Harkness, J. Bovine Virus Diarrhoea-Mucosal Disease Infection in Cattle. Vet. Rec. 1985, 117, 240-245. [CrossRef]

24. Kendrick, J.; Franti, C. Bovine Viral Diarrhea: Decay of Colostrum-Conferred Antibody in the Calf. Am. J. Vet. Res. 1974, 35, 589-592.

25. McGowan, M.; Kirkland, P.; Richards, S.; Littlejohns, I. Increased Reproductive Losses in Cattle Infected with Bovine Pestivirus Around the Time of Insemination. Vet. Rec. 1993, 133, 39-43. [CrossRef] [PubMed]

26. Viet, A.; Fourichon, C.; Seegers, H. Review and Critical Discussion of Assumptions and Modelling Options to Study the Spread of the Bovine Viral Diarrhoea Virus (BVDV) Within a Cattle Herd. Epidemiol. Inf. 2007, 135, 706-721. [CrossRef] [PubMed]

27. Baker, J. Bovine Viral Diarrhoea Virus: A Review. J. Am. Vet. Med. Assoc. 1987, 190, 1449-1458.

28. Moerman, A.; Straver, P.; de Jong, M.; Quak, J.; Baanvinger, T.; van Oirschot, J. A Long Term Epidemiological Study of Bovine Viral Diarrhoea Infections in a Large Herd of Dairy Cattle. Vet. Rec. 1993, 132, 622-626. [CrossRef] 
29. Carlsson, U.; Fredriksson, G.; Alenius, S.; Kindahl, H. Bovine Virus Diarrhoea Virus, a Cause of Early Pregnancy Failure in the Cow. J. Vet. Med. Ser. A 1989, 36, 15-23. [CrossRef]

30. Done, J.; Terlecki, S.; Richardson, C.; Harkness, J.; Sands, J.; Patterson, D.; Sweasey, D.; Shaw, I.; Winkler, C.; Duffell, S. Bovine Virus Diarrhoea-Mucosal Disease Virus: Pathogenicity for the Fetal Calf Following Maternal Infection. Vet. Rec. 1980, 106, 473-479. [CrossRef]

31. McClurkin, A.; Littledike, E.; Cutlip, R.; Frank, G.; Coria, M.; Bolin, S. Production of Cattle Immunotolerant to Bovine Viral Diarrhea Virus. Can. J. Comp. Med. 1984, 48, 156-161.

32. Kendrick, J.W. Bovine Viral Diarrhea-Mucosal Disease Virus Infection in Pregnant Cows. Am. J. Vet. Res. 1971, 32, 533-544. [PubMed]

33. Saltelli, A.; Chan, K.; Scott, E.M. Sensitivity Analysis; Wiley: New York, NY, USA, 2000.

34. Thulke, H.H.; Lange, M.; Tratalos, J.A.; Clegg, T.A.; McGrath, G.; O'Grady, L.; O'Sullivan, P.; Doherty, M.L.; Graham, D.A.; More, S.J. Eradicating BVD, Reviewing Irish Programme Data and Model Predictions to Support Prospective Decision Making. Prev. Vet. Med. 2018, 150, 151-161. [CrossRef]

35. Metcalfe, L. An Update on the Status of BVD Control and Eradication in Europe. J. Vet. Sci. Med. 2019, 7. [CrossRef]

36. Sayers, R.G.; Sayers, G.P.; Graham, D.A.; Arkins, S. Impact of Three Inactivated Bovine Viral Diarrhoea Virus Vaccines on Bulk Milk p80 (NS3) ELISA Test Results in Dairy Herds. Vet. J. 2015, 205, 56-61. [CrossRef]

37. Häsler, B.; Howe, K.S.; Presi, P.; Stärk, K.D. An economic model to evaluate the mitigation programme for bovine viral diarrhoea in Switzerland. Prev. Vet. Med. 2012, 106, 162-173. [CrossRef]

38. Jackova, A.; Novackova, M.; Pelletier, C.; Audeval, C.; Gueneau, E.; Haffar, A.; Petit, E.; Rehby, L.; Vilcek, S. The Extended Genetic Diversity of BVDV-1, Typing of BVDV Isolates from France. Vet. Res. Commun. 2008, 32, 7-11. [CrossRef] [PubMed]

39. Ridpath, J.F. Immunology of BVDV Vaccines: Biologicals, Aspects of Immunology of Bovine Viral Diarrhea. Virus 2013, 41, 14-19.

40. Lanyon, S.R.; Hill, F.I.; Reichel, M.P.; Brownlie, J. Bovine Viral Diarrhoea: Pathogenesis and Diagnosis. Vet. J. 2014, 199, 201-209. [CrossRef] [PubMed]

41. Cristancho-Fajardo, L.; Ezanno, P.; Vergu, E. Integrative Modelling of Pathogen Spread through Animal Trade by Accounting for Farmers' Control Decisions. Sci. Rep. 2021, 11. [CrossRef] 